\title{
Penyuluhan dan Pelatihan Pembuatan Sabun Padat Organik di Desa Peguyangan Denpasar
}

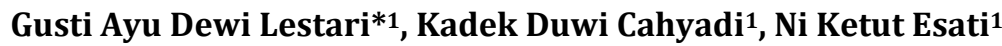 \\ 1Sekolah Tinggi Farmasi Mahaganesha \\ *e-mail: lestaridewi87@gmail.com
}

\begin{abstract}
Teenagers in Peguyangan Kangin Village, Denpasar, Bali still do not understand the process of making organic solid soap because they have never received training on making organic solid soap. The aim of community service is to provide counseling and training in the manufacture of organic solid soap made from raw materials coconut oil, palm oil and olive oil. Pretest and posttest were carried out before and after the activity which is one form of evaluation of this activity. The result of the activity showed that counseling and training on making organic solid soap had provided information and knowledge to the youth of Peguyangan Kangin Village and could have been carried out well by the participants.
\end{abstract}

Keywords: Organic Soap, Teenagers, Peguyangan Village, Bali

\begin{abstract}
Abstrak
Remaja atau pemuda pemudi di Desa Peguyangan Kangin Denpasar Bali, masih belum memahami proses pembuatan sabun padat organik karena belum pernah mendapatkan pelatihan tentang pembuatan sabun padat organik. Tujuan pengabdian kepada masyarakat ini adalah memberikan penyuluhan dan pelatihan pembuatan sabun padat organik berbahan baku minyak kelapa, minyak kelapa sawit dan minyat zaitun. Pretes dan posttest dilaksanakan sebelum dan sesudah kegiatan yang merupakan salah satu bentuk evaluasi dari kegiatan ini. Hasil kegiatan menunjukkan bahwa penyuluhan dan pelatihan tentang pembuatan sabun padat organik telah memberikan informasi dan pengetahuan kepada remaja Desa Peguyangan Kangin serta telah dapat dilakukan dengan baik oleh para peserta.
\end{abstract}

Kata kunci: Sabun Organik, Remaja, Desa Peguyangan, Bali

\section{PENDAHULUAN}

Banjar Jurang Asri berada dalam wilayah Desa Peguyangan Kangin Kota Denpasar. Desa ini memiliki luas wilayah sekitar 4,16 km². Batas-batas Desa Peguyangan Kangin yaitu di sebelah utara Desa Tonja, selatan Desa Peguyangan Kaja, Timur Desa Peguyangan dan barat Desa Peninjoan. Desa Peguyangan Kangin disahkan menjadi Desa pada tahun 2004 berdasarkan SK No. 15 tahun 2004. Dari segi pemerintahan, Desa Peguyangan Kangin terbagi atas 10 Banjar Dinas yaitu: Pengukuh, Jurang Asri, Bantas, Tunjung Sari, Purnama Asri, Peninjoan, Kayangan, Ambengan, Cengkilung dan Jenah. Jumlah penduduk Desa Peguyangan Kangin tercatat sebanyak 7.625 jiwa. Desa Peguayangan Kangin merupakan daerah pertanian dengan mayoritas petanian padi, peternakan sapi dan perkebunan. Desa Peguyangan Kangin memiliki Pasar terbesar yang bernama Pasar Agung yang pernah menjadi pasar percontohan di Denpasar. Di Desa Peguyangan Kangin yang dibeberapa wilayahnya sebagian kebun sangat memiliki potensi akan pohon kelapa dengan hasil buah kelapa yang banyak.

Disisi lain pengamatan di lapangan menunjukkan bahwa belum adanya pengetahuan dan keterampilan remaja atau STT Eka Dharma Santhi dalam teknologi kreativitas dalam pembutan sabun padat organik. Seperti yang kita ketahui memasuki era revolusi 4.0 generasi muda diharapkan tidak hanya sebagai penikmat karya tetapi juga dapat berkreasi dan berwirausaha dengan hasil pemikiran dan gagasan-gagasan baru. Dengan mengetahui cara pembuatan sabun padat organik ini diharapkan remaja atau STT Eka Dharma Santhi dapat menerapkan dan nantinya juga dapat berwirausaha dengan ide sabun organik ini. Pengolahan minyak kelapa, minyak kelapa sawit, minyak zaitun menjadi sabun padat organik sangat mudah dilakukan. Sabun merupakan pembersih yang dibuat dengan reaksi kimia antara basa natrium atau kalium dengan 
asam lemak dari minyak nabati atau lemak hewan (SNI, 1994). Ada 2 jenis sabun yang dikenal, yaitu sabun padat (batangan) dan sabun cair.

Sabun padat dapat dibedakan menjadi 3 jenis, yaitu sabun opaque, translucent, dan transparan. Sabun organik merupakan sabun yang dibuat dengan menambahkan minyak dalam formula sabun yang berfungsi sebagai penghalus kulit, pencegah jerawat, sekaligus sebagai aroma yang bersifat menenangkan. Sabun aromaterapi dibuat dengan mencampur beberapa bahan yaitu minyak, sodium hidroksida, pewangi dan pewarna. Pencampuran dilakukan pada suhu ruang dan setelah tercampur baru dicetak (Hambali et al., 2005). Jenis sabun yang banyak dikembangkan saat ini adalah sabun padat organik terutama untuk memenuhi kebutuhan industri jasa spa. Berdasarkan data yang dikompilasi dari industri kecantikan global, industri spa dunia termasuk Indonesia dan Bali mengalami peningkatan 7\% setiap tahun.

Seiring dengan semakin berkembangnya industri spa di Bali kebutuhan akan sabun padat organik juga meningkat. Sabun padat organik mempunyai peluang untuk dikembangkan di Desa Peguyangan Kangin melihat potensi kelapa yang selanjutnya diolah menjadi minyak kelapa. Minyak kelapa tersebut selanjutnya dapat digunakan sebagai bahan baku sabun. Sabun ini diberi aroma yang menyenangkan, dicetak dengan berbagai bentuk dan diberikan warna menarik, yang cocok disajikan untuk oleh-oleh atau untuk memenuhi kebutuhan industri jasa spa. Dengan demikian, pengembangan kegiatan pembuatan sabun padat organik diharapkan dapat dijadikan peluang usaha dalam rangka meningkatkan ekonomi keluarga.

Kegiatan pengabdian kepada masyarakat ini bertujuan memberikan penyuluhan tentang pembuatan sabun padat organik berbahan baku minyak kelapa, minyak kelapa sawit dan minyak zaitun serta memberikan pelatihan dan praktik tentang langkah-langkah pembuatan sabun padat organik berbahan baku minyak kelapa, minyak kelapa sawit dan minyak zaitun. Diharapkan dengan adanya penyuluhan dan pelatihan pembuatan sabun padat organik ini, remaja atau STT Eka Dharma Santhi dapat mengetahui dan memahami tentang proses pembuatan sabun padat organik sehingga nantinya menjadi ajang para remaja untuk berwirausaha.

\section{METODE}

Pelaksanaan kegiatan pengabdian ini dimulai dengan pelaksanaan penyuluhan dalam bentuk ceramah dalam ruangan dengan materi penyuluhan tentang pembuatan sabun padat organik berbahan minyak kelapa, minyak kelapa sawit, minyak zaitun dilengkapi formula pembuatan sabun dan proses pembuatan sabun aromaterapi. Tahapan selanjutnya adalah pelaksanaan pelatihan dan praktik langsung membuat sabun padat organik berbahan minyak kelapa, minyak kelapa sawit, minyak zaitun dengan aroma kopi, dengan melibatkan peserta secara langsung.

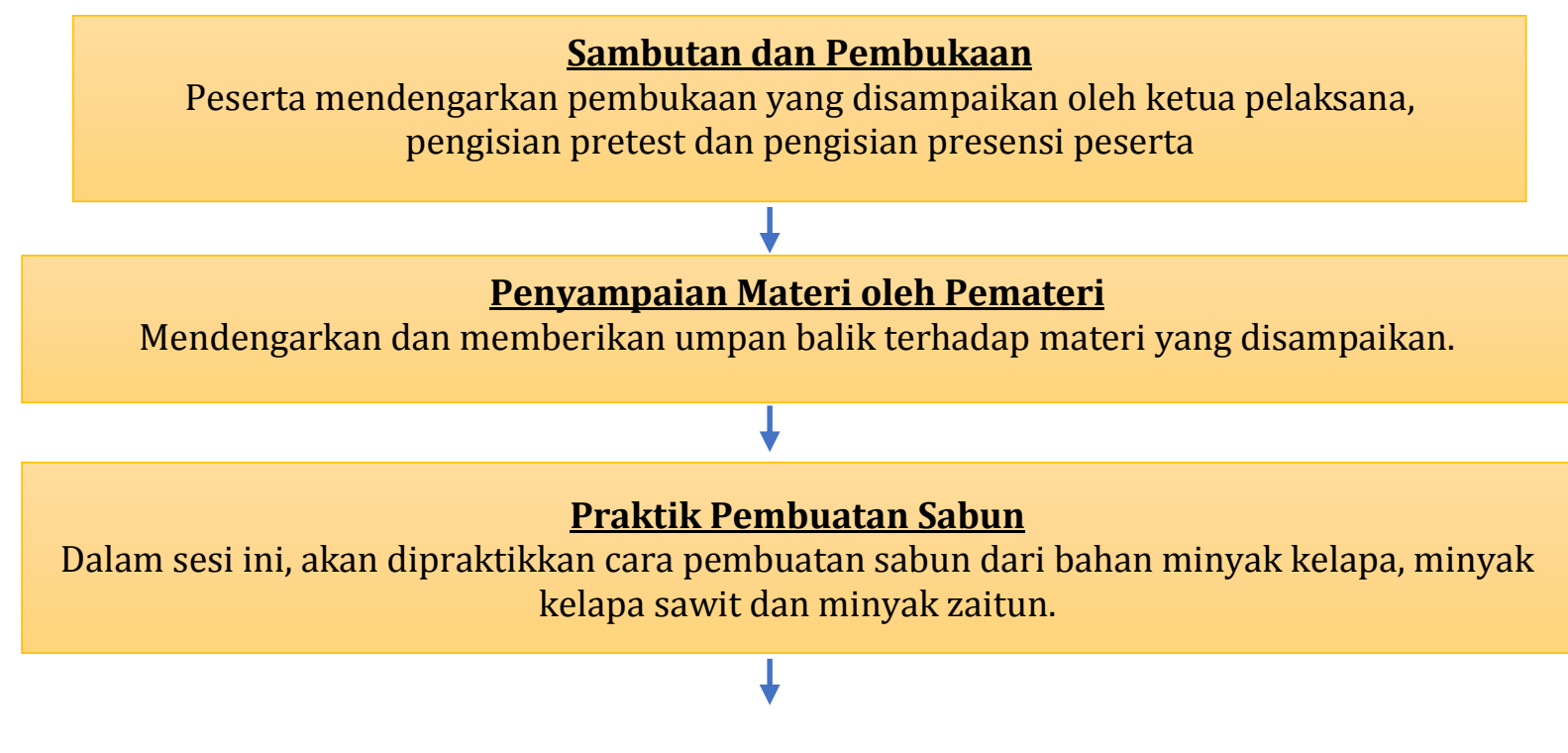




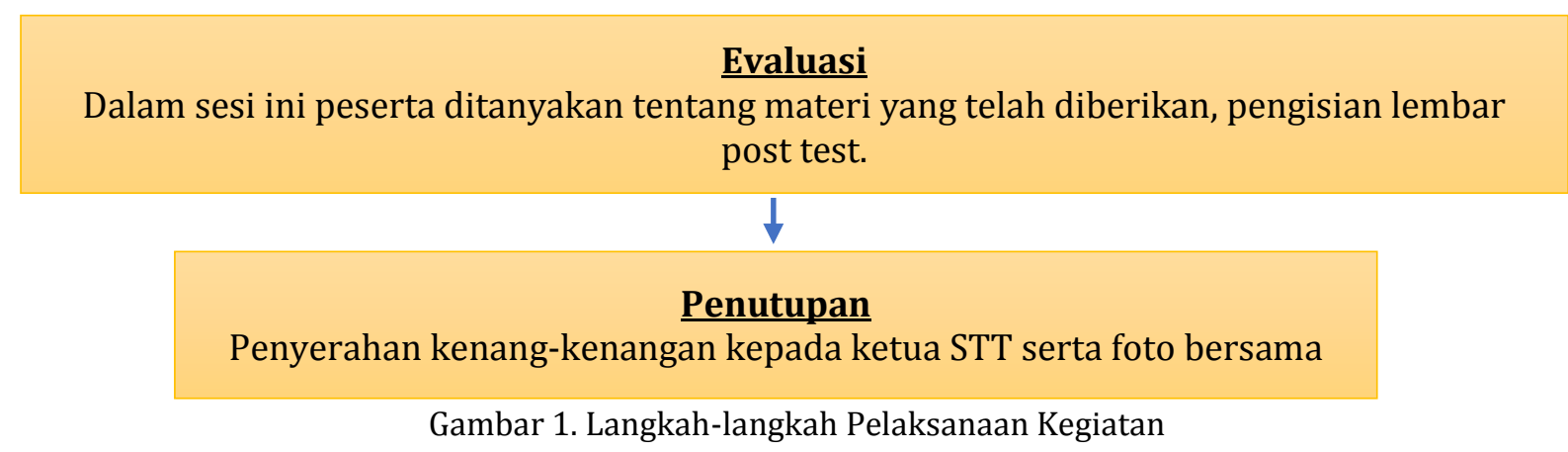

Persiapan kegiatan, meliputi koordinasi dengan Kepala Desa Peguyangan Kangin Denpasar untuk memohon ijin terlaksananya kegiatan ini di Balai Banjar Jurang Asri; koordinasi dengan Ketua Pemuda Pemudi untuk mempersiapkan peserta yang ikut dalam kegiatan dan persiapan alat dan bahan serta akomodasi.

Kriteria yang digunakan dalam mengevaluasi kegiatan pengabdian ini meliputi: (1) Peran serta aktif peserta selama ceramah saat sesi penyuluhan, melalui aktivitas selama diskusi serta umpan balik dan absensi atau daftar hadir. (2) Kemampuan peserta dalam pembuatan sabun padat organik selama pelatihan berlangsung, dengan menunjukkan hasil/produk sabun yang dihasilkan serta pretes dan posttes yang telah dilakukan oleh peserta

\section{HASIL DAN PEMBAHASAN}

Kegiatan pengabdian kepada masyarakat yang berlokasi di Desa Peguyangan Kangin Kecamatan Denpasar Utara Kota Denpasar telah dilaksanakan di Balai Banjar Jurang Asri. Kegiatan diikuti oleh 30 orang peserta dari remaja atau pemuda pemudi STT Eka Dharma Santhi. Tim Pelaksana sebanyak 10 orang mahasiswa. Kegiatan pengabdian meliputi penyuluhan dalam bentuk ceramah tentang pembuatan sabun padat organik berbahan minyak kelapa, minyak kelapa sawit dan minyak zaitun dilengkapi formulanya (Tabel 1.) serta praktik pembuatan sabun tersebut.

Tabel 1. Formula pembuatan sabun aroma terapi

\begin{tabular}{ccc}
\hline No & Nama Bahan & Komposisi \\
\hline 1 & Minyak kelapa & $30 \%$ \\
2 & Minyak kelapa sawit & $20 \%$ \\
3 & Minyak zaitun & $50 \%$ \\
4 & NaOH 27\% & $38 \%$ \\
5 & Pewarna dan aromaterapi & Secukupnya \\
\hline
\end{tabular}

Kegitan penyuluhan dan pelatihan pembuatan sabun aroma terapi telah dapat dilakukan dengan baik. Hal ini terlihat dari keseriusan perserta saat pelatihan pembuatan sabun aromaterapi.

Prosedur kerja cara pembuatan sabun aromaterapi adalah:

1. Minyak kelapa, minyak kelapa sawit dan minyak zaitun dicampur menjadi 1 dan diaduk-aduk

2. Dimasukkan $\mathrm{NaOH}$, diaduk sampai mencapai trace

3. Ditambahkan pewarna dan aromaterapi secukupnya

4. Adonan sabun diangkat dan dicetak, diamkan adonan sampai mengeras

5. Sabun dikemas dan disimpan selama \pm 6 minggu sebelum dapat digunakan 


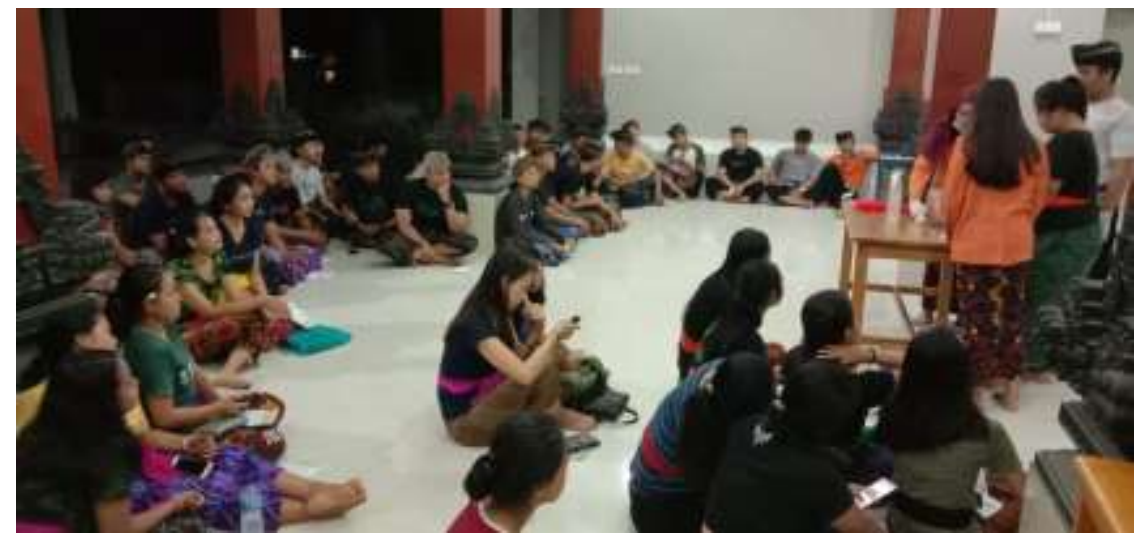

Gambar 2. Penjelasan Pembuatan Sabun dari Tim Pelaksana

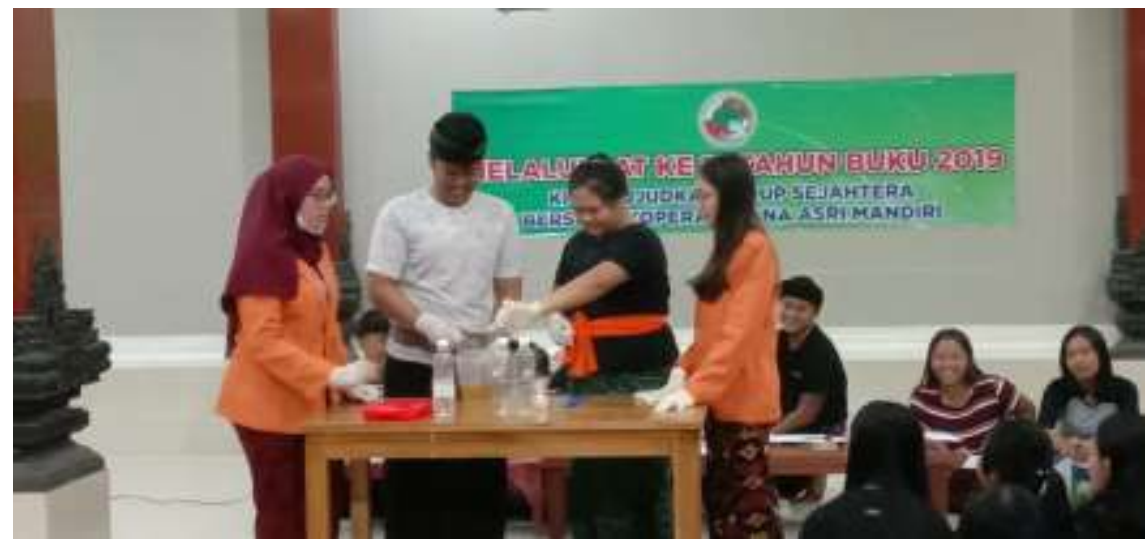

Gambar 3. Praktik Pembuatan Sabun langsung oleh para peserta

Berdasarkan penyuluhan yang dilakukan diperoleh hasil seperti yang tertera pada tabel 2 .

Tabel 2. Pemahaman peserta mengenai pembuatan sabun padat organik

\begin{tabular}{clcccc}
\hline \multicolumn{1}{c}{ Pertanyaan } & \multicolumn{3}{c}{ Persentase (\%) Jawaban Pertanyaan } \\
No & \multicolumn{2}{c}{$\begin{array}{c}\text { Sebelum Pelatihan } \\
\text { Ya }\end{array}$} & $\begin{array}{c}\text { Setelah Pelatihan } \\
\text { Ya }\end{array}$ & Tidak \\
\hline 1 & $\begin{array}{l}\text { Apakah anda telah memahami } \\
\text { teknik pembuatan sabun padat } \\
\text { organik dari bahan minyak? }\end{array}$ & $50 \%$ & $50 \%$ & $93 \%$ & $7 \%$ \\
2 & & & & \\
$\begin{array}{l}\text { Apakah anda mengenal bahan- } \\
\text { bahan yang digunakan untuk } \\
\text { pembuatan sabun padat organik? }\end{array}$ & $56 \%$ & $44 \%$ & $80 \%$ & $20 \%$ \\
3 & $\begin{array}{l}\text { Apakah anda telah dapat membuat } \\
\text { sabun padat organik secara } \\
\text { mandiri? }\end{array}$ & $33 \%$ & $67 \%$ & $63 \%$ & $37 \%$ \\
4 & $\begin{array}{l}\text { Apakah anda berminat membuat } \\
\text { sabun padat organik sendiri? } \\
\text { Apakah kegiatan penyuluhan dan } \\
\text { praktik pembuatan sabun padat } \\
\text { organik ini bermanfat bagi anda }\end{array}$ & $100 \%$ & 0 & $100 \%$ & 0 \\
\hline
\end{tabular}

Dari tabel 2 terlihat bahwa untuk pertanyaan nomor 1 terjadi peningkatan persentase setelah adanya pelatihan yaitu sebanyak 93\% koresponden sehingga dapat disimpulkan remaja atau pemuda pemudi STT Eka Dharma Santhi mulai memahami teknik pembuatan sabun padat organik. Untuk pertanyaan nomor 2 terjadi peningkatan persentase setelah adanya pelatihan sebanyak 80\% dimana remaja atau pemuda pemudi STT Eka Dharma Santhi mulai mengenal 
bahan-bahan yang digunakan untuk membuat sabun padat organik. Dari pertanyaan nomor 3, terjadi peningkatan persentase sebanyak $63 \%$ walaupun tidak mencapai angka diatas $80 \%$. Hal ini kemungkinan disebabkan dalam pembuatan sabun dibutuhkan keahlian untuk menangani bahan-bahan yang digunakan karena walaupun sabun ini adalah sabun organik namun bahan kimia yang digunakan tergolong keras dan harus berhati-hati dalam penggunaannya. Pertanyaan nomor 4, terjadi peningkatan persentase menjadi 86\%. Dapat dilihat dari pertanyaan nomor 4 bahwa antusias remaja atau pemuda pemudi STT Eka Dharma Santhi untuk dapat membuat sabun natural sendiri sangatlah besar karena sebelum pelatihan pun minat mereka untuk membuat sabun ini sendiri diatas $80 \%$. Dari pertanyaan nomor 5, dapat disimpulkan bahwa pelatihan pembuatan sabun padat organik ini sangat bermanfaat untuk mereka karena dapat menjadi pengetahuan dasar untuk dapat berkreasi dalam pembuatan sabun organik.

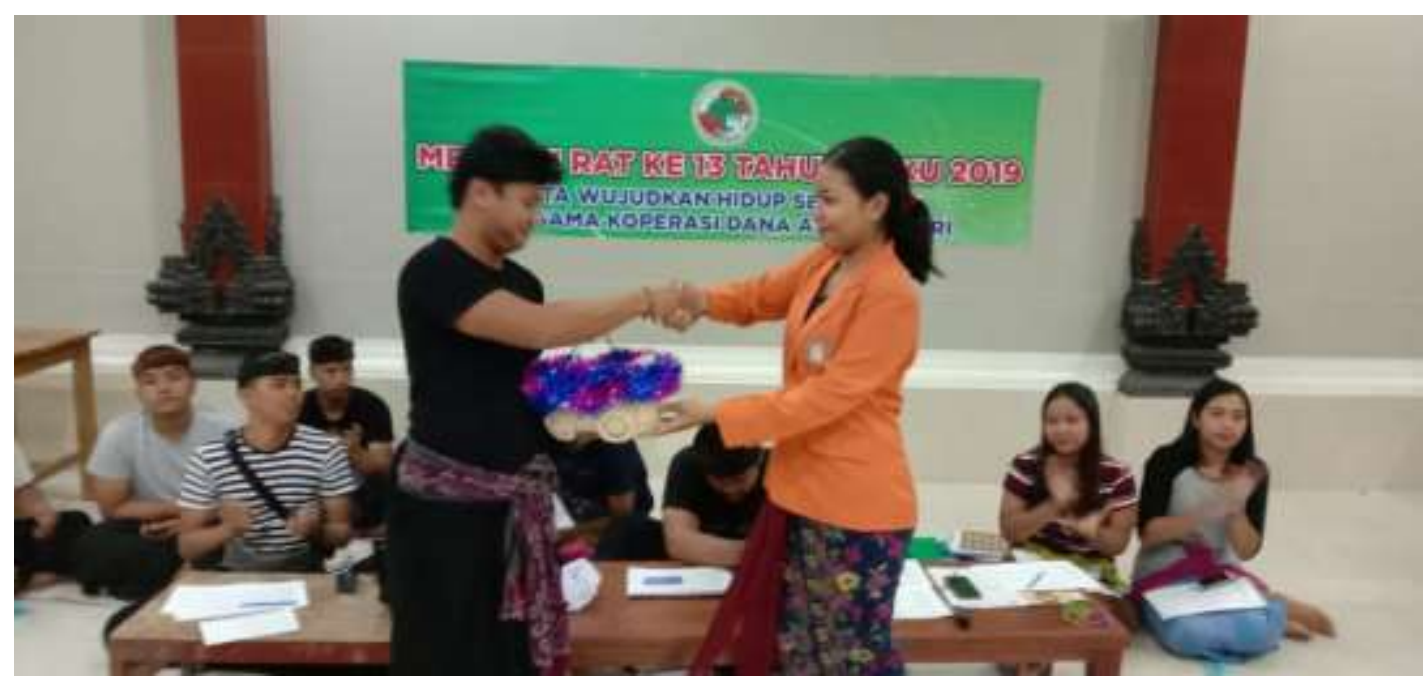

Gambar 4. Penyerahan kenang-kenangan kepada Ketua STT

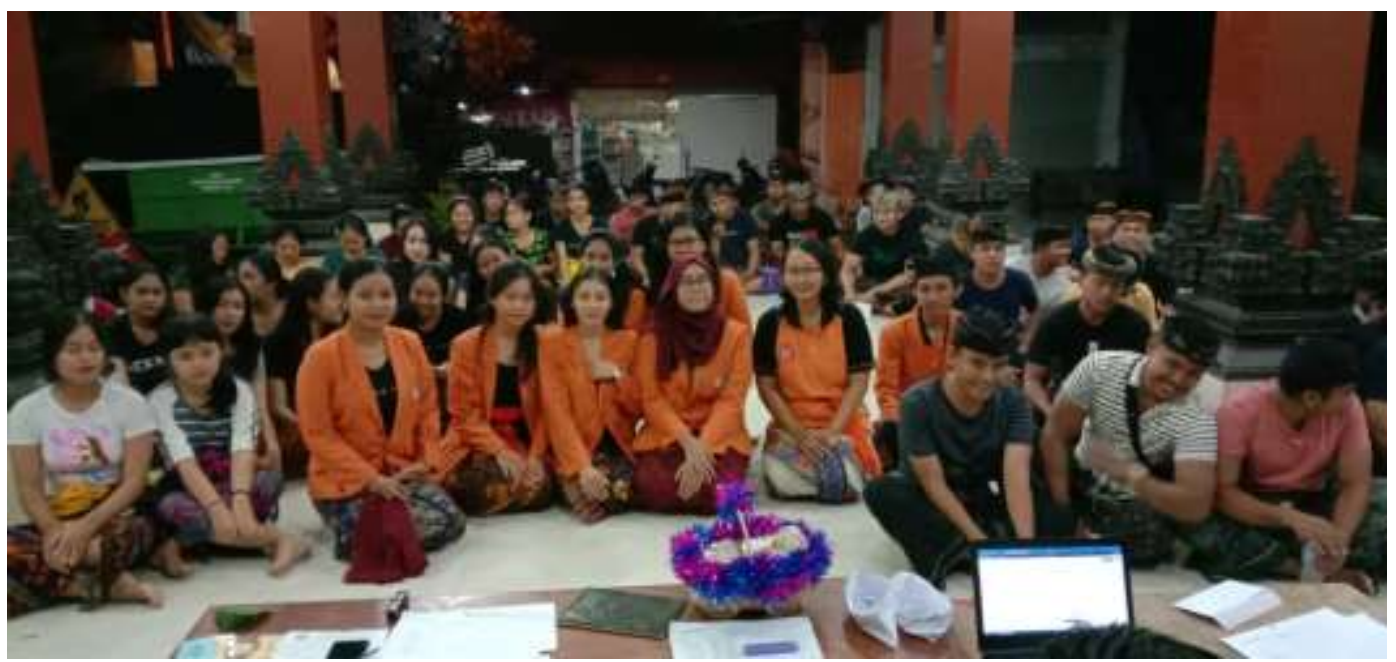

Gambar 5. Foto Bersama peserta pelatihan dengan tim pelaksana

\section{KESIMPULAN}

Kesimpulan dari kegiatan pengabdian kepada masyarakat yang telah dilakukan adalah sebagai berikut:

a. Penyuluhan tentang pembuatan sabun padat organik dari bahan minyak kelapa, minyak kelapa sawit dan minyak zaitun telah memberikan informasi dan pengetahuan yang diperlukan oleh masyarakat terutama remaja di Desa Peguyangan Kangin 
b. Pelatihan pembuatan sabun padat organik dari bahan minyak kelapa, minyak kelapa sawit, minyak zaitun dapat dilakukan dengan baik oleh para peserta.

c. Penyuluhan dan pelatihan pembuatan sabun ini disambut antusiasme yang tinggi dari para remaja di Desa Peguyangan Kangin agar ke depannya mereka mampu berkreasi membuat sabun sendiri dan berwirausaha sendiri.

\section{SARAN}

Program pengabdian ini diharapkan dapat ditindaklanjuti di lokasi lain pada tahun-tahun berikutnya untuk memberi pengetahuan pada masyarakat tentang cara memproduksi sabun padat organik sendiri di rumah.

\section{UCAPAN TERIMA KASIH}

Ucapan terimakasih disampaikan kepada segenap remaja atau pemuda pemudi Banjar Jurang Asri Desa Peguyangan Kangin Denpasar sehingga kegiatan ini dapat terlaksana dengan baik.

\section{DAFTAR PUSTAKA}

Badan Standarisasi Nasional. (1994). Standar Mutu Sabun Mandi. SNI 06-3532-1994. Dewan Standardisasi Nasional. Jakarta.

Departemen Kesehatan R.I. (1996). Mutu dan Cara Uji Sabun Mandi. Direktorat Jenderal Pengawasan Obat dan Makanan, Jakarta.

Dunn, K. M. (2010). Scientific Soapmaking: The Chemistry of The Cold Process. Clavicula Press

Hambali, E., A. Suryani, dan M. Rifai. (2005). Membuat Sabun Transparan untuk Gift dan Kecantikan. Penebar Swadaya, Jakarta

Hartini, S., Soetjipto, H., Ryanto, C. A., Cahyanti, M. N., \& Hastuti, D. K. A. K. (2017). Pemberdayaan Anggota PKK di Desa Lembu dalam Membuat Kosmetik. Agrokreatif Jurnal Ilmiah Pengabdian Kepada Masyarakat, 2(2): 81-86

Hermani. (2010). Formula Sabun Transparan Antijamur dengan Bahan Aktif Ekstrak Lengkuas (Alpinia galanga L.). Balai Besar Penelitian dan Pengembangan Pascapanen Pertanian. Jurusan Teknologi Industri Pertanian Fakultas Teknologi Institut Pertanian Bogor. Bogor

Kusuma. (2019). Desa Peguyangan Kangin. http://peguyangankangin.denpasarkota.go.id. Diakses 3 Pebruari 2020.

Mabrouk, S. T. (2005). Making Usable, Quality Opaque or Transparent Soap. Journal of Chemical Education, 82(10), 1534. Retrieved from https://doi.org/10.1021/ed08

Putra,G., N.M Wartini, L.P. Wrasiati, I.W.G.S.Yoga. (2016). Penyuluhan Dan Pelatihan Pembuatan Sabun Aroma Terapi Dari Minyak Kelapa Pada KWT "WIGUNA MEKAR" Di Desa Angkah, Kecamatan Selemadeg Barat, Kabupaten Tabanan. Program Studi Teknologi Industri Pertanian Fakultas Teknologi Pertanian. Universitas Udayana.

Sari, E., Jumiati, Wahyuni, S. (2020). Sosialisasi Pemanfaatan Jambu Air Menjadi Nata De Syzygium. Jurnal Pengabdian Kepada Masyarakat. 4(2): 209-213

Widyasanti, A., Putri, S.H., Dwiratna S.N.P. (2016). Upaya Pemberdayaan Masyarakat Melalui Pelatihan Pembuatan Produk Sabun Berbasis Komoditas Lokal Di Kecamatan Sukamantri Ciamis. Jurnal Aplikasi Ipteks untuk Masyarakat. 5(1): 29 - 33. 